\title{
PRE- AND POSTOPERATIVE COMPUTED TOMOGRAPHY IN PLANNING AND POSTOPERATIVE EVALUATION AFTER AUTOLOGOUS FLAP RECONSTRUCTION
}

\author{
Shchekoturov I.O., Bakhtiozin R.F., Istranov A.L., \\ Serova N.S., Babkova A.A., Kornev D.O.
}

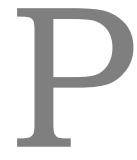

urpose. To determine the possibilities of multi-slice computed tomography (MSCT) with contrast enhancement at the pre- and postoperative assessment of flaps, donor and recipient zone.

Materials and methods. The study involved 96 patients (100\%) with different pathology, who underwent autologous flap transplantation at pre- and postoperative stages.

Results. All flaps were successfully harvested and transplanted. Both immediate and long-term examination showed good appearance reconstruction. All followed-up patients conveyed good satisfaction degree with function and appearance reconstruction. Postoperative computed tomography examination with contrast enhancement did not show hemodynamically significant areas of narrowing or anastomotic failure in arterial vessels.

Conclusions. Computed tomography with contrast enhancement is a valuable tool that can enhance the precision of preoperative planning and postoperative assessment for free flap reconstruction.

Keywords: flap, mastectomy, mandibular resection, TRAM, phalloplasty, MSCT.

Corresponding author: Shchekoturov I.O., e-mail: samaramail@bk.ru

For citation: Shchekoturov I.O., Bakhtiozin R.F., Istranov A.L., Serova N.S., Babkova A.A., Kornev D.O. Pre- and postoperative computed tomography in planning and postoperative evaluation after autologous flap reconstruction. REJR 2020; 10(3):113-119.

DOI:10.21569/2222-7415-2020-10-3-113-119.

Received: $\quad 20.04 .20 \quad$ Accepted: $\quad 19.06 .20$

\section{ПРЕА- И ПОСАЕОПЕРАЦИОННАЯ КОМПЬЮТЕРНАЯ ТОМОГРАФИЯ В ПААНИРОВАНИИ И ПОСАЕОПЕРАЦИОННОМ ОБСАЕАОВАНИИ ПАЦИЕНТОВ ПОСАЕ РЕКОНСТРУКТИВНО-ПААСТИЧЕСКИХ ОПЕРАЦИЙ С ИСПОАЬЗОВАНИЕМ АУТОЛОСКУТОВ}

\author{
Щекотуров И.О., Бахтиозин Р.Ф., Истранов А.^., \\ Серова Н.С., Бабкова А.А., Корнев А.О.
}

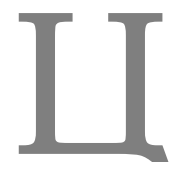

ель исследования. Определить возможности мультиспиральной компьютерной томографии (МСKT) с контрастным усилением дмя до- и послеоперационной оценки москутов, донорской и реципиентной зоны.

Материалы и методы. Обследовано 96 пациентов (100\%) с разцичной патологией, перенесших аутотранспиантацию москута на до- и послеоперационном этапе.

Результаты. Забор и пересадка всех москутов были проведены успешно. Обследование в раннем и позднем послеоперационном периоде продемонстрировали нормальное восстановление внешнего вида. Все пациенты, находившиеся под наблюдением, были удовцетворены восстановцением функции и внешнего вида. Послеоперационное компьютерно-томографическое исследование с контрастированием не выявило гемодинамически значимых участков сужения или несостоятельности анастомозов в ар-

ФГАОУ ВО Первый МГМУ имени И.М. Сеченова Минздрава России (Сеченовский Университет). Москва, Россия. 


\section{RUSSIAN ELECTRONIC JOURNAL OF RADIOLOGY}

териальных сосудах.

Выводы. Компьютерная томография с контрастным усилением - ценный метод, который может повысить точность предоперационного планирования и послеоперационной оценки при реконструкции свободными москутами.

Ключевые слова: москут, мастэктомия, резекция нижней чемюсти, TRAM, фамлопластика, MCKT.

Контактный автор: Щекотуров И.О., e-mail: samaramail@bk.ru

Для иитирования: Щекотуров И.О., Бахтиозин Р.Ф., Истранов А.А., Серова Н.С., Бабкова А.А., Корнев Д.О.. Пред- и послеопераиионная компьютерная томография в планировании и послеопераиионном обследовании паииентов после реконструктивнопластических операиий с использованием аутолоскутов. REJR 2020; 10(3):113-119. DOI: 10.21569/2222-7415-2020-10-3-113-119.

\section{Статья получена: $\quad$ 01.06.20 Статья принята: $\quad \begin{aligned} & 19.08 .20 \\ & \text { С }\end{aligned}$}

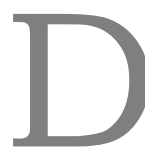

ifferent flap reconstruction has gained popularity over the past decade as a means of providing excellent aesthetic results with not expressed donor site morbidity [1-2].

Breast cancer is the second most common malignancy in women in Russian Federation [3]. Mastectomy remains a mainstay for treatment of breast cancer. With increasing frequency, women who undergo mastectomy for breast cancer treatment or for prophylaxis when their breast cancer risk is high also choose to undergo reconstructive surgery to restore the appearance of the breast [4]. Various options for breast reconstruction exist. Most women choose either silicone or adjustable saline implants, although the choice may commit them to undergo multiple surgical procedures in order to achieve a natural and long-lasting cosmetic result. The use of autologous tissue in place of silicone or saline implants offers a more durable result with less likelihood of complications. Traditionally, autologous reconstructions were performed by using musculocutaneous pedicle flaps (e.g., transverse rectus abdominis myocutaneous (TRAM) flap) [5].

Mandibular defects after extensive resection, due to tumors and other pathology, are quite disfiguring and can lead to significant cosmetic and functional deficiency. The reconstruction of the resected mandible could be performed with free bone grafts or a variety of implantable constructions. These operations have special application for those situations in which the bone defect is large, the recipient bed is poorly vascularized, and there is an associated soft tissue deficiency. The donor sites now include the fibula, iliac crest, rib, metatarsal, radius, and scapula [6].

Mandibular resection due to carcinologic imperatives or congenital/post-traumatic malformation affects not only facial esthetics but also swallowing, breathing and speech. Fibular free flap mandibular reconstruction has become the gold standard, since its first description by Hidalgo in 1989. Esthetic and functional restoration is all the more challenging as resection is large and complex, involving multiple segments of the mandible. Surgical success is based on maintaining symmetry and repositioning all bone segments, and especially the condyle, in their pre-operative positions to ensure stable dental occlusion [7].

Nowadays, a large number of different diseases of the urogenital region, both congenital and acquired, are distinguished. The methods of microsurgical autotransplantation of tissue complex can be used for the urogenital pathology treatment. Congenital hypoplasia of the penis can be corrected by substitutional integration phalloplasty with free revascularized and reinnervated microsurgical thoracodorsal autograft. Urethral stricture and obliteration are common pathologies that can be eliminated by replacement integration urethroplasty using free revascularized and reinnervated microsurgical radial autograft [8-9].

Success of the reconstruction, however, relies upon accurate assessment of highly variable soft and bone tissue vasculature for flap design and harvest. In the past few years, different radiological methods of examination and virtual planning have been increasingly used in plastic surgery at the pre- and postoperative stages of reconstruction using various autografts [10].

\section{Purpose.}

To determine the possibilities of modern radiological method multi-slice computed tomography (MSCT) with contrast enhancement at the pre- and postoperative assessment of flaps, donor and recipient zone.

Materials and methods.

In the period from 2017 to 2020 in the Radiology Department of Sechenov University Clinical 


\begin{tabular}{|c|c|c|}
\hline \multicolumn{2}{|c|}{ Table №1. Distribution of patients by pathology and treatment. } \\
\hline Disease & Flap type & Number of examined patients \\
\hline Breast cancer & TRAM flap & $14(15 \%)$ \\
\hline Mandibular defects & Fibula or rib flap & $3(3 \%)$ \\
\hline Urethral stricture & Radial flap & $37(39 \%)$ \\
\hline Pathology of penis & Thoracodorsal flap & $42(43 \%)$ \\
\hline
\end{tabular}

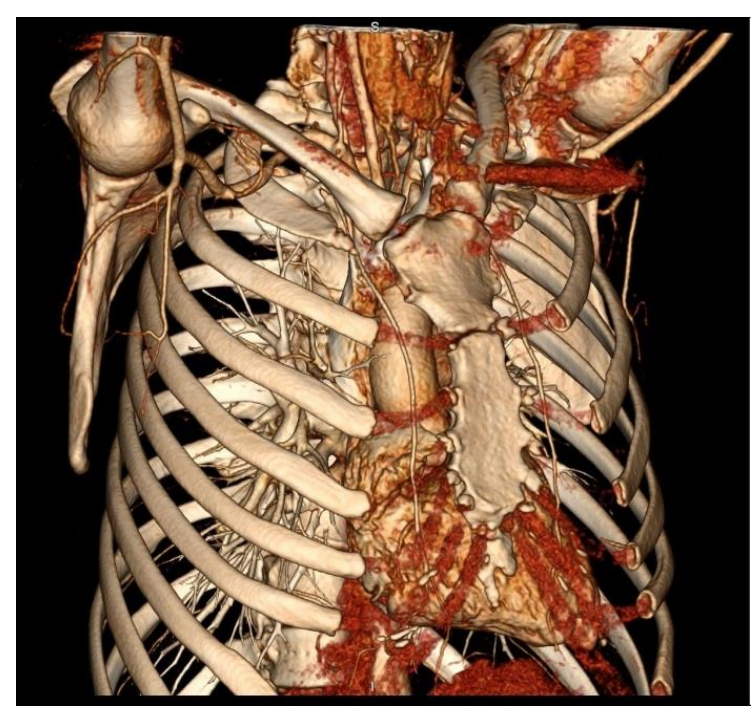

Fig. 1 (Рис. 1)

Fig. 1. Computed tomography, arterial phase, 3D reconstruction.

Preoperative examination for evaluation of thoracodorsal vessels before phalloplasty by thoracodorsal flap.

Рис. 1. Компьютерная томография, артериальная фаза, трехмерная реконструкция.

Предоперационное обследование дмя оценки торакодорсального сосудистого пучка перед фаллопластикой торакодорсальным цоскутом.

Hospital № 1, 96 patients (100\%), (average age of $44,3 \pm 4,5$ years) with different diseases, who underwent autotransplantation of flaps at pre- and postoperative stages were examined (Table 1).

All patients underwent pre- and postoperative CTA to determine blood supply of the abdomen, head, chest or lower extremities depending on the existing pathology. CT scans were performed according to a standard protocol in a supine position, patients holding the breath and not moving during acquisition using a 640 multi-slice CT scanner (Toshiba Aquillion One, Japan) with $120 \mathrm{kV}, 120 \mathrm{mAs}$ and $0,5 \mathrm{~mm}$ slice thickness. The intravenous catheter was placed in the antecubital arm vein, and $70-90 \mathrm{ml}$ of a contrast agent injection containing $370 \mathrm{mg}$ of iodine per milliliter (Ultravist 370, Germany) at a rate of 4 milliliter/second was administered. Bolus tracking was performed for the chest or abdominal aorta region, and then was performed imaging of head, chest, abdomen or lower extremities on the zone of interest. Arterial phase was performed for determining of arterial blood supply of donor and recipient zone. Venous phase was performed for examination of parenchymal organs and state of soft and bone tissues. The average calculated effective dose was about $7,3 \pm 2,1 \mathrm{mSv}$.

\section{Results.}

The analysis of CT angiograms was performed on images in the axial plane, as well as their sagittal, coronal and $3 \mathrm{D}$ reconstructions. The most informative were images in the axial plane. They allow to make an objective assessment of the soft tissues and the vessels.

For all patients, the vascular anatomy of the recipient and donor vessels was assessed with a description of atypical variants of blood supply and measurement of the length and diameter of all arteries.

The average distance between the axillary artery and the bifurcation of the thoracodorsal artery was $79 \pm 12 \mathrm{~mm}$. The average distance between the subscapularis artery and the bifurcation of the thoracodorsal artery was $38 \pm 6 \mathrm{~mm}$. The average distance between the bifurcation of the thoracodorsal artery and the end of the distal segment of the descending branch, as well as the end of the distal segment of the transverse branch, was $96 \pm 15$ and $74 \pm 11 \mathrm{~mm}$, respectively (Fig. 1).

The average diameter of the axillary artery was $6.5 \pm 2.4 \mathrm{~mm}$, the average diameter of the subscapular artery was $4.1 \pm 1.9 \mathrm{~mm}$, and the average diameter of the thoracodorsal artery was 3.5 $\pm 1.7 \mathrm{~mm}$.

The classification introduced by Moon and Taylor in 1988 was used to assess the variant anatomy of the deep lower epigastric arteries.

The average determined length of the right inferior epigastric artery was $183 \pm 22 \mathrm{~mm}$, and the average length of the left inferior epigastric artery - $179 \pm 26 \mathrm{~mm}$. The mean diameter of the right inferior epigastric artery at the ostium was $3.1 \pm 0.9 \mathrm{~mm}$. The mean diameter of the left inferior epigastric artery at the ostium was $3.1 \pm 0.9$ $\mathrm{mm}$.

According to the Moon and Taylor classifica 


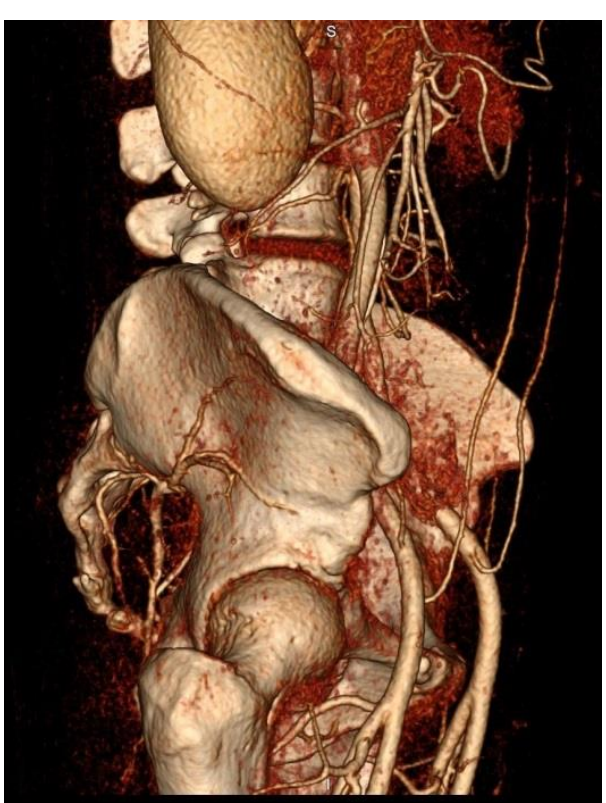

Fig. 2 a (Рис. 2 a)

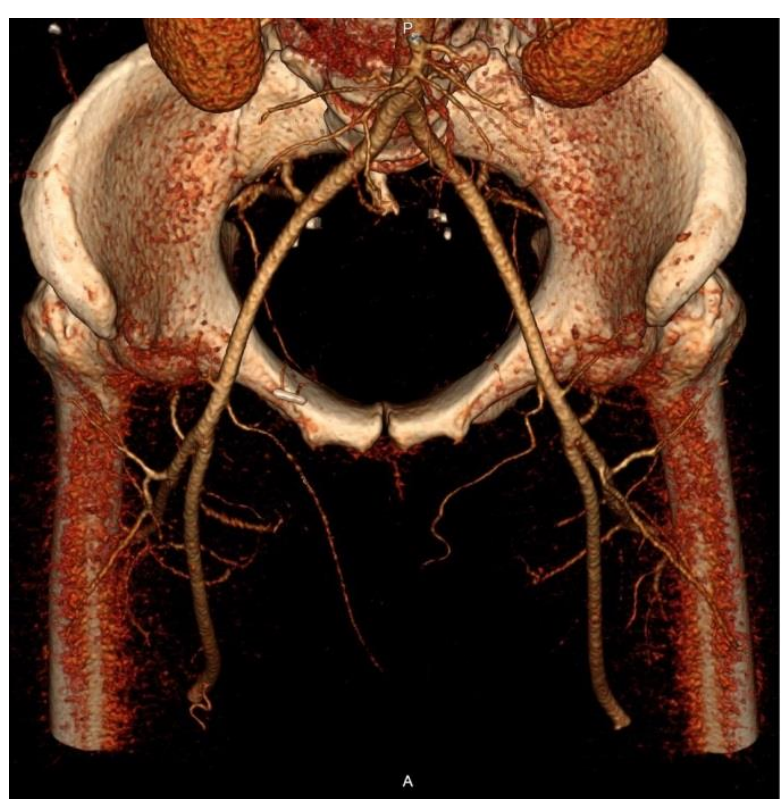

Fig. 2 b (Рис. 2 б)

\section{Fig. 2. Computed tomography, arterial phase, 3D reconstruction.}

A - Preoperative examination of epigastric vessels before phalloplasty by thoracodorsal flap. Moon and Taylor type I.

B - Postoperative examination of epigastric vessels after phalloplasty by thoracodorsal flap and urethroplasty by radial flap. Lower epigastric arteries deviated down.

\section{Рис. 2. Компьютерная томография, артериальная фаза, трехмерная реконструкция.}

А - Предоперационное исследование эпигастральных сосудов перед фалмопластикой торакодорсальным москутом. Тип I согласно классификации сосудистой анатомии по Moon and Taylor.

Б - Компьютерная томография, артериальная фаза, трехмерная реконструкция. Послеоперационное исследование эпигастральных сосудов после фаллопластики торакодорсальным москутом и уретропластики мучевым москутом. Нижние эпигастральные артерии низведены.

tion, type I of the right lower epigastric artery was found in 53 (57\%) patients, type II in 24 (35\%) patients, type III in $5(8 \%)$ patients. Type I branching of the left inferior epigastric artery was found in $41(60 \%)$ patients, type II in $23(34 \%)$ patients, type III in $4(6 \%)$ patients (Fig. 2).

After the postoperative arterial series data processing not a single patient had hemodynamically significant areas of narrowing or anastomotic failure.

By measuring the thickness of the thoracodorsal flap, the required width of the thoracodorsal flap can be determined so that the reconstructed urethra can be placed in it without clamping the free radial flap. The optimal diameter of the reconstructed urethra is $1.5 \mathrm{~cm}(\mathrm{r}=0.75$ $\mathrm{cm})$. If $X$ is the thickness of the thoracodorsal flap, then $(X+0.75) \times 2 \pi$ is equal to the circumference of the phallus and corresponds to the width of the required flap (Fig. 3 a-b). The length of the flap was selected in accordance with the wishes of the patients.

A total of 14 consecutive patients underwent pre and postoperative CTA, prior to reconstruc- tion. The majority of patients were undergoing delayed reconstruction following invasive ductal carcinoma of the breast.

For all patients, the vascular anatomy of the recipient and donor vessels was assessed. Recipient vessels were inferior epigastric arteries and donor vessels were internal mammary vessels. The mean diameter of the internal mammary arteries at the ostium was $3.3 \pm 1.1 \mathrm{~mm}$. The average length of the internal mammary arteries were 315 $\pm 26 \mathrm{~mm}$ (Fig. 5).

At the postoperative period 3 patients with defects of the lower jaw underwent repeated reconstructive and restorative surgeries, including free autobone transplantation (fibula or rib flap), application of the distraction osteogenesis method in order to restore the lost volume of bone tissue (Fig. 5 a-d).

The number of reconstructive operations ranged from 3 to 5 in different patients. The rehabilitation time was on average 18-24 months (individually in each case).

Discussion.

The vessel selected for free flap depends on 


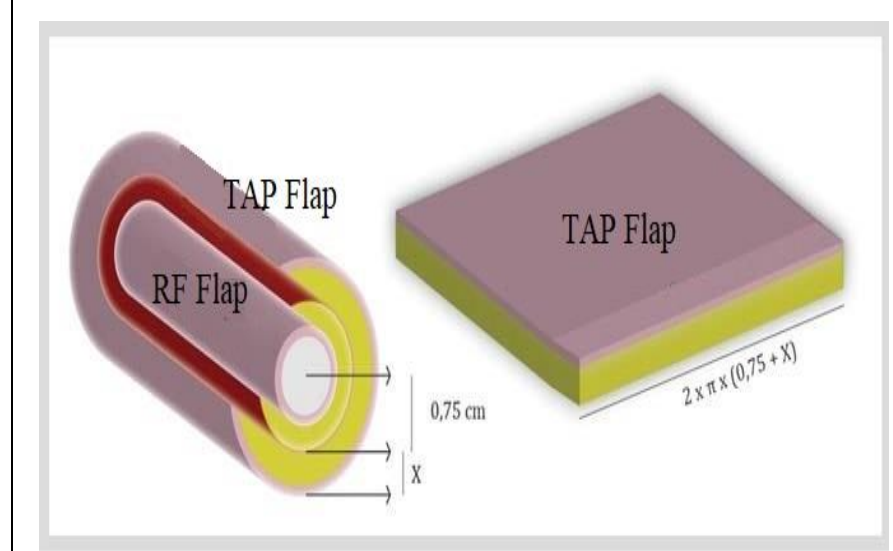

Fig. 3 a (Рис. 3 a)

Fig. 3 a. Scheme for determining the recommended width of the thoracodorsal flap, based on its thickness.

TAP Flap - Thoracodorsal Artery Perforator Flap.

RF Flap - Radial Forearm Flap.

Рис. 3 а. Схема опрелеления рекоменауемой ширины торакоАорсального ^оскута, основанная на его толщине.

TAP Flap - торакодорсальный цоскут RF Flap - мучевой

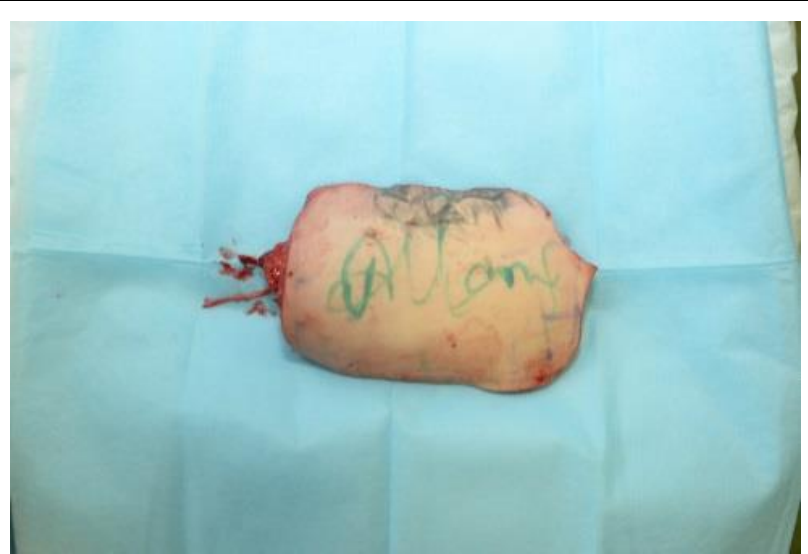

Fig. 3 b (Рис. 3 б)

Fig. 3 b. Photo.

Intraoperative photo of thoracodorsal artery flap.

Рис. 3 б. Фото.

Интраоперационное фото выделенного тодракодорсального москута.

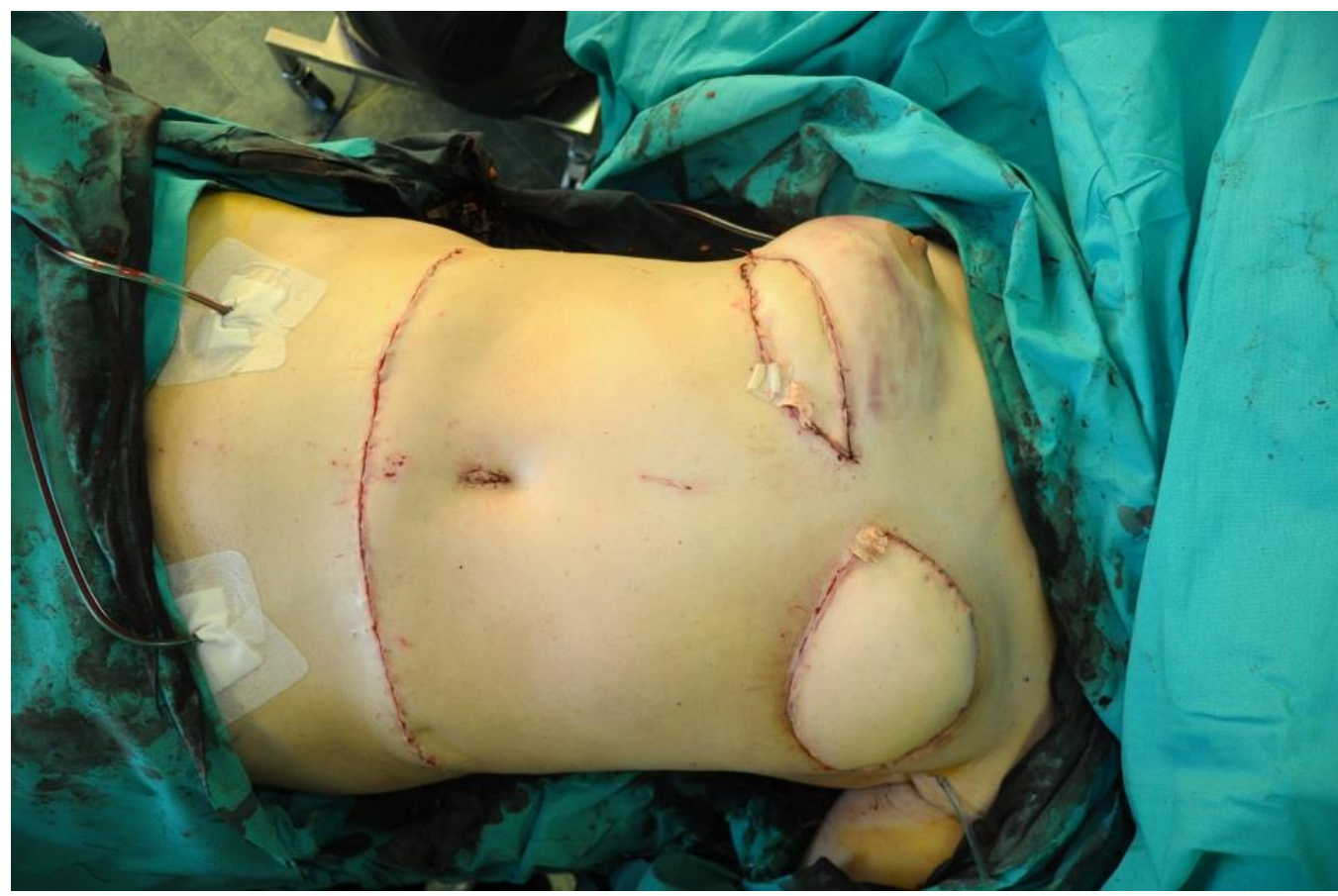

Fig. 4 (Рис. 4)

Fig. 4. Intraoperative photo.

State after autologous TRAM flap breast reconstruction.

Рис. 4. Интраоперационное фото.

Состояние после реконструкции молочной железы TRAM-^оскутом. 


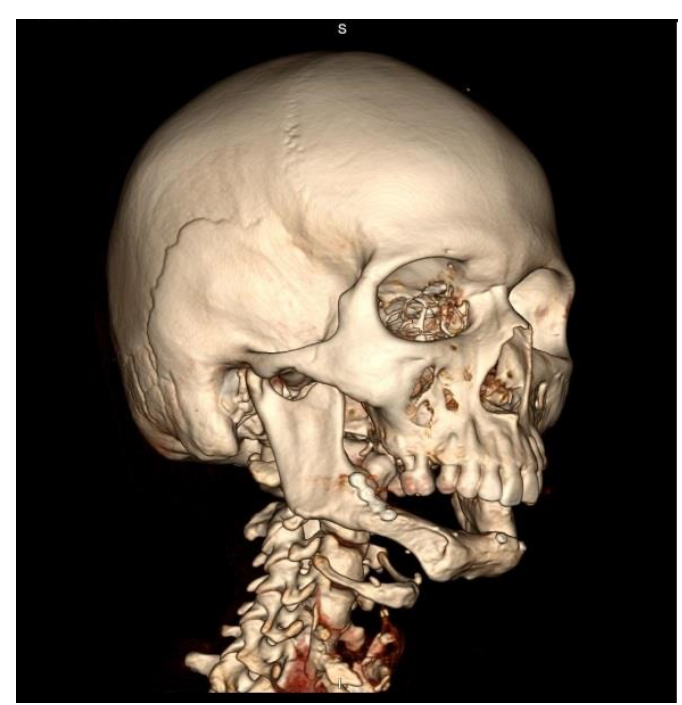

Fig. 5 a (Рис. 5 a)

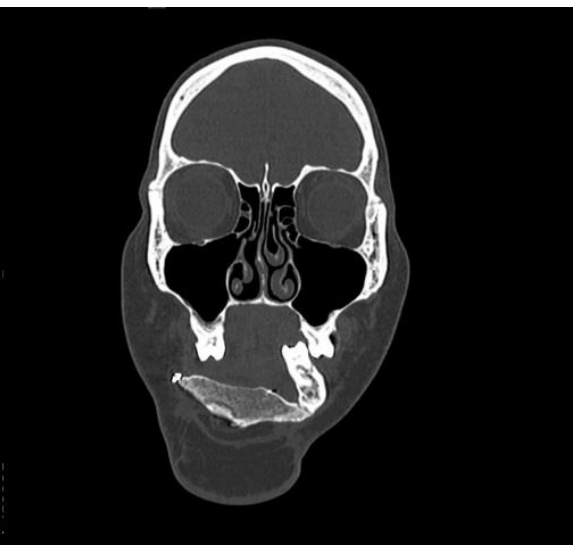

Fig. 5 с (Рис. 5 в)

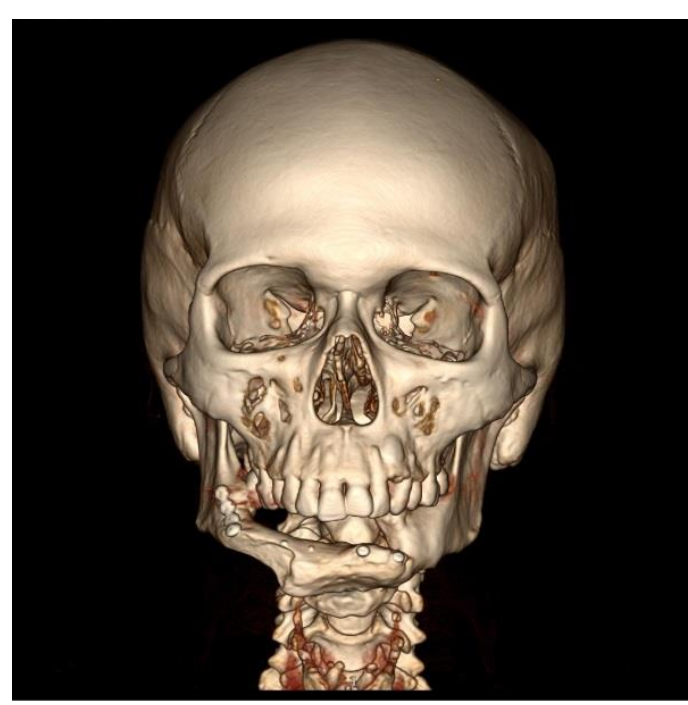

Fig. 5 b (Рис. 5 б)

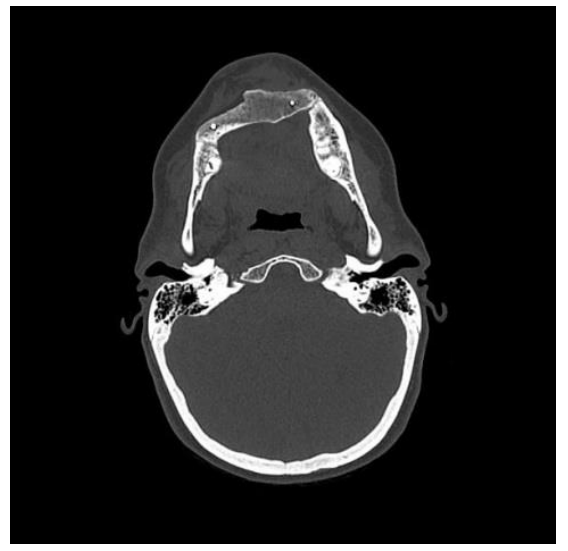

Fig. 5 d (Рис. 5 г)

Fig. 5. Computed tomography, 3D reconstruction ( $a, b)$, coronal plane (c), axial plane (d).

State after mandibular resection and reconstruction by rib flap.

Рис. 5. Компьютерная томография, трехмерная реконструкция (а,б), корональная реконструкция (в), аксиальная проекция (г).

Состояние после резекции нижней челюсти и реконструкции реберным москутом.

multiple anatomic and surgical considerations, and the decision-making process can be exceptionally time-consuming, in part because of the wide variation that occurs in vascular anatomy. Preoperative imaging can greatly improve the efficiency of the selection process. The computed tomographic angiographic evaluation performed with the use of specific postprocessing and display techniques may be more accurate for identifying the most suitable vessel. CT angiography provides valuable information that can help optimize surgical planning, decrease time spent in the operating room, and improve the outcome of reconstruction surgery [11].

The arteries have many variable anatomic features, including its location, its branching pat tern, and the number of perforating vessels that it supplies. In addition, a superficial inferior epigastric artery that can be used as a vascular pedicle is present in only two thirds of candidates for breast reconstruction [12].

In patients who have undergone abdominal surgery, these vessels, particularly the superficial inferior epigastric artery, might be distorted or even absent [13].

CT with virtual planning in mandibular reconstruction by fibular free flap can increase symmetry compared to traditional freehand conformation. Computer-assisted surgery improves mandibular bony landmark positioning, particularly for the condyles, ensuring morphological results as close as possible to the native mandible, 


\section{RUSSIAN ELECTRONIC JOURNAL OF RADIOLOGY}

notably in complex reconstruction involving multiple segments [14-17].

\section{Conclusion.}

Computed tomography with contrast enhancement is a valuable tool that can enhance the precision of preoperative planning for free flap reconstruction. Knowledge of the relevant anatomy, surgical technique, and protocols for acquiring

\section{References:}

1) Vargas C.R., Koolen P.G., Ho O.A., Tobias A.M., Lin S.J., Lee B.T. Preoperative CT-angiography in autologous breast reconstruction. Microsurgery. 2016; 36 (8): 623-627. doi:10.1002/micr.30065.

2) Chae M.P., Hunter-Smith D.J., Rozen W.M. Comparative analysis of fluorescent angiography, computed tomographic angiography and magnetic resonance angiography for planning autologous breast reconstruction. Gland Surg. 2015; 4 (2): 164 178. doi: 10.3978/j.issn.2227-684X.2015.03.06.

3) Kvasha E.A., Kharkiv T.L. Statistical and demographic analysis of mortality from breast cancer in Russia. Questions of statistics. 2006; 8: 25-33.

4) Hu E.S., Pusic A.L., Waljee J.F., et al. Patient-reported aesthetic satisfaction with breast reconstruction dur-ing the longterm survivorship period. Plast. Recon $\urcorner$ str. Surg. 2009; 124 (1): $1-8$.

5) Hartrampf C.R., Scheflan M., Black P.W. Breast reconstruction with a transverse abdominal island flap. Plast. Reconstr. Surg. 1982; 69 (2): 216-225.

6) Dolgolev A., Reshetov I., Svyatoslavov D., Sinelnikov M., Kudrin K., Dub, V., Anikin V. Experimental Biointegration of a Titanium Implant in Delayed Mandibular Reconstruction. Journal of Personalized Medicine. 2020: 10 (1): 6. doi:10.3390/jpm10010006.

7) Hidalgo DA, Pusic AL. Free-flap mandibular reconstruction: a 10-year follow-up study. Plast. Reconstr. Surg. 2002; 110: 438449.

8) Schekoturov I.O., Istranov A.L., Serova N.S., Ternovoy S.K., Bakhtiosin R.F., Adamyan R.T., Matevosyan A.V. Complex radiology diagnostic at the pre-and postoperative stages in patients with the reconstruction of the urogenital area using the method of microsurgical autotransplantation of tissue complexes. REJR. 2018; 8 (3): 205-212. DOI: 10.21569/2222-7415-2018-8-3-205212.

9) Istranov A.L., Shchekoturov I.O., Bakhtiosin R.F., Serova N.S., Adamyan R.T., Matevosyan A.V. Use of volumetric dynamic voiding multispiral computed cystourethrography in diagnosis and interpreting $\mathrm{CT}$ angiograms can help reduce procedure time and lead to better outcomes.

Benefits of preoperative CT for vessels assessment include excellent reproducibility, high resolution, potential for $3 \mathrm{D}$ reconstructions, widespread availability, and high sensitivity and specificity. Postoperative CT gives useful information about autograft state and it's blood supply.

and evaluation of treatment efficiency of congenital and acquired pathology of the urogenital area. Urologiia. 2019; 5: 53 58. Doi://dx.doi.org/10.18565/urology.2019.5.53-58.

10) Bartier S., Mazzaschi O., Benichou L., Sauvaget E. Computer-assisted versus traditional technique in fibular free-flap mandibular reconstruction: A CT symmetry study. European Annals of Otorhinolaryngology, Head and Neck Diseases. 2020. doi:10.1016/j.anorl.2020.06.011.

11) Aubry S., Pauchot J., Kastler A., et al. Preoperative imaging in the planning of deep inferior epigastric artery perforator flap surgery. Skelet. Radiol. 2013; 42 (3): 319-327.

12) Strauch B., Yu H.L. Groin region. In: Atlas of microvascular surgery: anatomy and operative approaches. New York, NY, Thieme, 1993. PP. 120-122.

13) Scott J.R., Liu D., Said H., Neligan P.C., Mathes D.W. Computed tomographic angiography in planning abdomen-based microsurgical breast reconstruction: a comparison with color duplex ultrasound. Plast. Reconstr. Surg. 2010; 125 (2): 446453.

14) Ghattaura A., Henton J., Jallali N., et al. One hundred cases of abdominal-based free flaps in breast reconstruction: the impact of preoperative computed tomographic angiography. J Plast. Reconstr. Aesthet. Surg. 2010; 63 (10): 1597-1601.

15) Babkova A.A., Serova N.S., Basin E.M., Kureshova D.V., Pasha S.P., Kornev A.I. Radiological diagnosis of facial osteonecrosis in patients taking desomorphine. REJR. 2014; 4 (2): 109114.

16) Babkova A.A., Serova N.S., Medvedev Yu. A. Complex radiological diagnosis of facial bones in desomorphine dependence patients on the preoperative stage of treatment. REJR 2019; 9 (1): 16-26. DOI:10.21569/2222-7415-2019-9-1-16-26.

17) Chae M.P., Hunter-Smith D.J., Rozen W.M. Comparative analysis of fluorescent angiography, computed tomographic angiography and magnetic resonance angiography for planning autologous breast reconstruction. Gland Surg. 2015; 4: 164 178. 